\title{
Metodevurderinger: Kunnskapsbasert beslutningsstøtte på overordnet nivå i helsetjenesten
}

\author{
Brynjar Fure, Vigdis Lauvrak, Helene Arentz-Hansen, Åse Skår, Sari Susanna Ormstad, \\ Vidar Jusnes Vang og Katrine Bjørnebek Frønsdal \\ Seksjon for spesialisthelsetjenesten, Nasjonalt kunnskapssenter for helsetjenesten \\ Korrespondanse: Brynjar Fure, Seksjon for spesialisthelsetjenesten, Nasjonalt kunnskapssenter for helsetjenesten \\ E-post: brynjar.fure@kunnskapssenteret.no Telefon: 45426388
}

\begin{abstract}
SAMMENDRAG
I Norge har vi siden slutten av 1990-tallet utført metodevurderinger om effekt av tiltak i helsetjenesten som støtte til beslutningstakere. Metodevurderingene ble frem til 2004 utført ved Senter for medisinsk metodevurdering, og deretter ved Nasjonalt kunnskapssenter for helsetjenesten, som i dag er landets nasjonale metodevurderingsorganisasjon. Metodevurderinger kan i prinsippet brukes som beslutningsstøtte på alle nivåer i helsetjenesten, men i praksis benyttes metodevurderinger først og fremst som en del av et kunnskapsbasert beslutningsgrunnlag på overordnet politisk eller administrativt nivå. Hovedhensikten med metodevurderinger er å bidra til at gode og nyttige metoder kommer raskt ut til pasientene.

Med metoder menes alle tiltak som er aktuelle i helsetjenesten, både legemidler, medisinsk utstyr, prosedyrerelatert diagnostikk og behandling, screening og organisatoriske tiltak. Metodevurderingene sammenfatter først og fremst kunnskapsgrunnlaget om klinisk effekt og sikkerhet, men ofte inngår også en helseøkonomisk evaluering. Her benyttes en strikt og etterprøvbar metodikk utarbeidet av anerkjente og veletablerte internasjonale metodevurderingsmiljøer. Avhengig av hva slags metode det er snakk om, vurderes også andre aspekter, som for eksempel etiske, sosiale, organisatoriske eller juridiske konsekvenser av å innføre metoden. For å sikre metodevurderingenes relevans i de kliniske miljøene, inviteres vanligvis kliniske spesialister til å delta $\mathrm{i}$ arbeidet.

Metodevurderingsorganisasjoner samarbeider i økende grad med søsterorganisasjoner i andre land, ikke bare rundt forskning og utvikling av metodikken som benyttes i metodevurderinger, men også ved å dele resultater fra metodevurderinger, og dermed unngå dobbeltarbeid.

En metodevurdering oppsummerer utelukkende forskningsresultatene om en metode, og inneholder ingen anbefaling om hvorvidt metoden bør innføres i helsetjenesten.
\end{abstract}

Fure B, Lauvrak V, Arentz-Hansen H, Skår Å, Ormstad SS, Vang VS, Frønsdal KB.

Health Technology Assessment: Knowledge-based decision support at the superior level in the health services. Nor J Epidemiol 2013; 23 (2): 165-169.

\section{ENGLISH SUMMARY}

In Norway, Health Technology Assessment (HTA) has existed since the late 1990s as support for decision makers in the health services. Until 2004, HTA was performed at the Norwegian Centre for Health Technology Assessment and later at the Norwegian Knowledge Centre for the Health Services which is, today, the national HTA-organization in Norway. HTA may be used as decision support at all levels in the health services. However, in practice, HTA is mainly used as part of evidence-based decisions by politicians or health leaders. The main purpose of HTA is to contribute to rapid introduction of useful health technologies, for the benefit of the patients.

HTA may be used for all types of health technologies, including pharmaceuticals, medical devices, diagnostic and therapeutic procedures, screening and organizational measures. In HTA-reports, the evidence regarding effect and safety of a technology is summarized, and, in most cases, also include a health economic evaluation. A strict and transparent methodology, developed by well-established international HTA-agencies, is used. Other aspects such as ethical, social, organizational or legal consequences of the technology may be evaluated, depending on the technology. In order to make HTA clinically relevant, clinical experts are usually invited to participate in the work.

HTA-organizations, increasingly, collaborate with HTA-organizations in other countries, not only in order to develop the methodology of HTA, but also to share the results of HTA-reports, and, thus, avoid double work.

An HTA-report summarizes the research results on a technology, and gives no advice regarding the decision that should be made about the introduction of the new technology. 


\section{BAKGRUNN}

Metodevurderinger har blitt utarbeidet i Norge siden slutten av 1990-tallet da Senter for medisinsk metodevurdering (SMM) ble etablert av det daværende Sosialog helsedepartementet (1). Arbeidet med å vurdere og kvalitetssikre nye metoder i helsetjenesten startet i USA allerede på 1970-tallet, og har senere spredt seg til Europa, Canada, Australia og andre deler av verden. Hovedhensikten med metodevurderinger har helt fra starten av vært å bidra til at gode og nyttige metoder kommer raskt ut til pasientene. Nasjonalt kunnskapssenter for helsetjenesten (Kunnskapssenteret) ble etablert i 2004, og er i dag Norges nasjonale metodevurderingsorganisasjon. Metodevurderinger utføres imidlertid også av andre aktører i helsetjenesten, for eksempel mini-metodevurderinger som utføres lokalt $\mathrm{i}$ helseforetakene $(2,3)$.

\section{Metode som begrep}

Health Technology Assessment (HTA) er den internasjonale betegnelsen på en metodevurdering. Begrepet "helseteknologi" (health technology) kan imidlertid være utfordrende på norsk, ettersom klinikere og helseledere kan oppfatte "helseteknologi" som ensbetydende med medisinsk utstyr som benyttes til diagnostikk eller behandling i den kliniske helsetjenesten, som for eksempel en røntgen- eller ultralydmaskin. I denne sammenheng omfatter begrepet "helseteknologi" mye mer enn bare medisinsk utstyr, og i Norge er det derfor bestemt at man bør benytte det norske ordet metode som i prinsippet inkluderer alle typer tiltak som brukes i helsetjenesten, både legemidler, medisinsk utstyr, prosedyrerelatert diagnostikk og behandling, screening og organisatoriske tiltak.

\section{HVA ER EN METODEVURDERING?}

\section{Innholdet $i$ en metodevurdering}

En metodevurdering skal gi beslutningsstøtte for kunnskapsbasert helsepolitikk og praksis. Den mest sentrale delen $i$ en metodevurdering er en oppsummering av klinisk effekt og sikkerhet. Når det foreligger flere studier vedrørende ulike effekter av en metode, vil det ofte være aktuelt å oppsummere disse i en systematisk oversikt, og om mulig vurdere den samlede effekten ved hjelp av metaanalyser (4-6). Innhenting av forskningsgrunnlaget skjer ved systematisk litteratursøk, vanligvis utført av bibliotekar med spesialkompetanse. Oppsummering av forskningsresultatene innebærer at effektestimatene trekkes ut av forskningspublikasjonene, og vurderes med hensyn til kvalitet, både for den samlede forskningsdokumentasjonen av metoden og for de enkelte studiene. Målet er at den som skal bruke metodevurderingen, både får en presentasjon av resultatene og en vurdering av om disse er pålitelige.

De fleste metodevurderinger inneholder en helseøkonomisk analyse. Den helseøkonomiske delen av en metodevurdering består ofte av en kostnadseffektivitetsanalyse hvor kvalitetsjusterte leveår benyttes som mål på helsegevinst ved eventuell innføring av metoden. I tillegg er det for en del metoder aktuelt å vurdere organisatoriske, sosiale, juridiske og etiske konsekvenser av å innføre metoden.

\section{Involverte i utarbeidelsen en metodevurdering}

Utarbeiding av en metodevurdering er et teambasert, tverrfaglig arbeid hvor forskere, bibliotekarer, helseøkonomer og eventuelt etikere, jurister eller sosiologer, samarbeider om å oppsummere forskningsresultatene. Ofte deltar også kliniske spesialister med inngående kjennskap til den aktuelle pasientgruppen. Hensikten med et slikt tverrfaglig samarbeid er å sikre at en internasjonalt akseptert metodikk for innhenting og kvalitetsvurdering av forskningsgrunnlaget følges samtidig som metodevurderingen har relevans for den del av helsetjenesten som er brukere av den nye metoden.

\section{HVORDAN KAN METODEVURDERINGER BRUKES?}

\section{Bruk av metodevurderinger på ulike nivåer $i$ helsetjenesten}

Metodevurderinger utføres for å støtte kunnskapsbaserte beslutninger i helsetjenesten, og innebærer at kunnskapsgrunnlaget for en metode, samt mulige konsekvenser av eventuell innforing av metoden blir belyst. I prinsippet kan alle beslutningsnivåer i helsetjenesten benytte metodevurderinger som beslutningsstøtte, men i praksis er det ofte beslutningstakere på nasjonalt, regionalt eller annet overordnet nivå som er brukere av metodevurderinger. På nasjonalt nivå benyttes metodevurderinger blant andre av Stortinget, Helse- og omsorgsdepartementet, Nasjonalt råd for kvalitet og prioritering i helse- og omsorgstjenesten, Helsedirektoratet og Statens legemiddelverk (Legemiddelverket). Også frivillige organisasjoner og profesjonsforeninger kan ha nytte av metodevurderinger, for eksempel i forbindelse med utforming av organisasjonens satsingsområder.

På regionalt nivå kan de regionale helseforetakene bruke metodevurderinger som støtte i beslutninger vedrørende innføring av ny diagnostikk eller behandling, organisatoriske modeller $\mathrm{i}$ helsetjenesten eller funksjonsfordeling innad i helseregionen. Det er også mulig å bruke metodevurderinger lokalt i helseforetakene, selv om større beslutninger basert på metodevurderinger ofte fattes sammen med det regionale helseforetaket.

\section{Bruk av metodevurderinger når det foreligger uenighet}

På overordnet politisk nivå kan metodevurderinger benyttes når det skal fattes beslutninger om vanskelige helserelaterte temaer i samfunnet, særlig når det foreligger uenighet om nytten eller etiske konsekvenser av å innføre en metode. Ett eksempel er Kunnskapssenterets metodevurdering fra 2012 vedrørende tidlig ultralyddiagnostikk i svangerskapet der vi, foruten å 


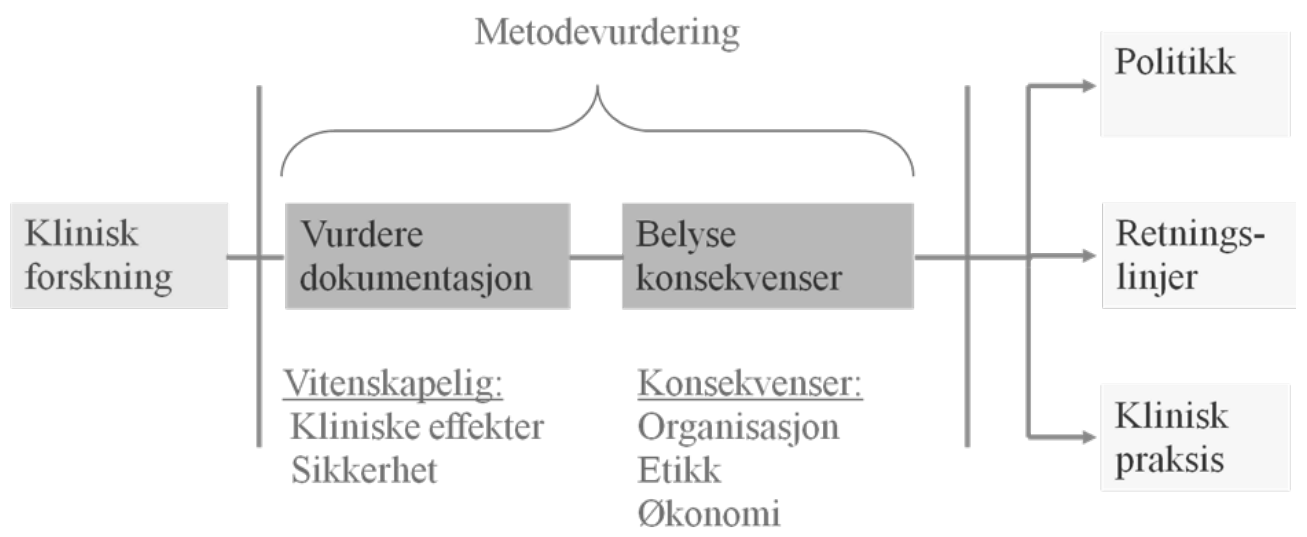

Figur 1. Figuren illustrerer at metodevurderinger vurderer vitenskapelig dokumentasjon og belyser effekter av forskningsresultater før de tas i bruk som beslutningsgrunnlag innen politikkutforming, nasjonale retningslinjer eller klinisk praksis.

oppsummere effekt og sikkerhet ved denne metoden, også belyste helseøkonomiske og etiske konsekvenser av å innføre rutinemessig tidlig ultralydundersøkelse i svangerskapsuke 11-13 (7). Denne metodevurderingen ble brukt av Nasjonalt råd for kvalitet og prioritering i sine anbefalinger til politikerne, og senere også som kunnskapsgrunnlag for politikere fra flere partier på Stortinget. Et annet eksempel er en metodevurdering fra 2013 om effekt og kostnadseffektivitet av nye antikoagulerende legemidler (8). Denne ble brukt som kunnskapsgrunnlag i Legemiddelverket.

\section{Bruk av metodevurderinger i utarbeidelser av retningslinjer og nasjonale anbefalinger}

Helsedirektoratet utarbeider nasjonale retningslinjer i Norge. Disse er styrende for klinisk praksis, både i spesialist- og kommunehelsetjenesten, og bygger så langt mulig på oppsummert forskning. Et eksempel er de nasjonale krefthandlingsplanene som på en systematisk måte har brukt oppsummert kunnskap som grunnlag for anbefalingene. Metodevurderinger tas ofte inn som beslutningsstøtte i arbeidet med å utforme slike overordnede nasjonale anbefalinger.

\section{Kunnskapshull}

Metodevurderinger kan i tillegg avdekke kunnskapshull og identifisere behov for videre forskning, særlig for forskning som ikke nødvendigvis blir finansiert av private interesser. Ved tildeling av offentlige forskningsmidler kan metodevurderinger dermed bidra til at forskning utføres på helseområder hvor det er viktig for samfunnet å fremskaffe ny kunnskap.

\section{NYTT SYSTEM FOR NYE METODER I HELSETJENESTEN}

\section{Manglende styring ved innforing av nye metoder}

Selv om noen sykehus har systemer for å vurdere nye metoder før innføring, har det lenge vært klart, både for helsemyndigheter, sykehusledere og mange klinikere at innføring av nye metoder i den norske helsetjenesten ofte skjer uten en overordnet styring. For legemidler har det i flere år eksistert et system for vurdering og innføring av nye metoder, men for medisinsk utstyr, prosedyrerelaterte diagnostiske og terapeutiske metoder samt for organisatoriske tiltak har innføringen ofte foregått uten at forskningsdokumentasjon og konsekvenser ved bruk av metoden har vært grundig vurdert på forhånd. Kunnskapssenteret og Legemiddelverket har i mange år utført metodevurderinger, men $\mathrm{i}$ den kliniske helsetjenesten har det så langt ikke vært krav om metodevurderinger før innføring av nye metoder.

\section{Nasjonalt system for innforing av nye metoder}

I 2013 innfører Helse- og omsorgsdepartementet et nytt system for vurdering av nye metoder. Metodevurderinger vil være en integrert del av dette nye systemet, og fungere som et verktøy for å understøtte beslutninger på ulike nivåer $\mathrm{i}$ helsetjenesten. I systemet inngår mini-metodevurderinger (3) som en basis for vurdering av nye metoder på sykehusnivå, men det legges også opp til at større vurderinger kan utføres på nasjonalt nivå, både $\mathrm{i}$ form av hurtige og fullstendige metodevurderinger. Hurtige metodevurderinger innebærer vurdering av effekt, sikkerhet og kostnadseffektivitet for en enkelt metode, for eksempel et legemiddel eller medisinsk utstyr, mens fullstendige metodevurderinger innebærer en mer omfattende vurdering hvor flere aspekter inngår, for eksempel etiske eller organisatoriske konsekvenser av metoden, alternativt en vurdering av flere metoder mot hverandre. I tillegg skal det innenfor rammen av det nye systemet bygges opp en norsk metodevarslingstjeneste etter modell av utenlandske "horizon scanning" organisasjoner hvor helsetjenesten får varsling om metoder som kan bli aktuelle for markedet i løpet av de neste 2-3 år. Hensikten med dette er at helseforetakene skal være best mulig forberedt for budsjettmessige og organisatoriske konsekvenser av potensielle nye metoder. I det nye systemet vil Kunnskapssenteret og Legemiddelverket være utførere av metodevurderinger på nasjonalt nivå, mens de fire regionale helseforetakene og Helsedirektoratet vil være sentrale aktører innen prioritering og bestilling av 
metodevurderinger på nasjonalt nivå. Den overordnede hensikten med dette nye og helhetlige systemet er å kunne gi pasientene en rask, god og trygg behandling samt bidra til rasjonell bruk av ressursene i helsetjenesten. Også ved utfasing av etablerte metoder som erstattes av nye, kan metodevurderinger være en viktig del av beslutningsgrunnlaget.

\section{INTERNASJONALT SAMARBEID OM METODEVURDERINGER}

\section{Samarbeid om metodevurderinger i Europa}

Nasjonalt kunnskapssenter for helsetjenesten har som den nasjonale metodevurderingsorganisasjonen i Norge et tett samarbeid med søsterorganisasjoner, for eksempel gjennom det europeiske nettverket "European Network for Health Technology Assessment" (EUnetHTA) (9). I dette nettverket deltar de fleste europeiske land, inkludert Norge, sammen i en såkalt "Joint Action", finansiert av EU-kommisjonen. Målsetningene for EUnetHTA er å forbedre og videreutvikle metodikken som benyttes ved metodevurderinger, samt å utføre felles metodevurderinger som er aktuelle for flere land slik at dobbeltarbeid kan unngås. Selv om økonomiske og etiske konsekvenser ved en metode ofte vil være forskjellig fra land til land, vil resultater om klinisk effekt og sikkerhet være like. Derfor legges det opp til at disse resultatene fra metodevurderingene skal deles med de andre europeiske landene.

Internasjonalt samarbeid om metodevurderinger pågår kontinuerlig, for eksempel mellom de nordiske land som gjerne har en ganske lik oppfatning, ikke bare av klinisk effekt og sikkerhet ved en metode, men også av etiske og andre konsekvenser.

\section{Samarbeid om metodevurderinger globalt}

"Health Technology Assessment international" (HTAi) (10) er en verdensomspennende organisasjon som bidrar til utvikling av metodikk og utveksling av kunnskap om metodevurderinger, blant annet gjennom en årlig internasjonal kongress. Norge deltar aktivt $\mathrm{i}$ HTAi, både ved bidrag på kongressen og i arbeidsgrupper innen spesielt viktige felt knyttet til metodevurdering, for eksempel informasjonsgjenfinning, utfasing av ineffektive metoder og pasientinvolvering.

Et annet globalt nettverk hvor Norge deltar aktivt er "International Network of Agencies for Health Technology Assessment" (INAHTA) (11). Dette er et nettverk for nasjonale og regionale organisasjoner som jobber med metodevurdering. Nettverket skal fremme samarbeid og kunnskapsdeling blant medlemsorganisasjonene, formidle nytten av metodevurderinger til ulike målgrupper og hindre unødig dobbeltarbeid.

\section{DISKUSJON}

En viktig grunn for å utføre metodevurderinger er å kartlegge forskningsdokumentasjon og konsekvenser knyttet til kontroversielle metoder. Slike metoder kan involvere etiske, religiøse eller juridiske spørsmål hvor det ikke er gitt hvilken konklusjon som er riktig, verken for politikere, klinikere eller lekfolk. I noen tilfeller kan metoder utfordre menneskeverdet i livets siste fase, $i$ fosterstadiet eller $i$ andre utsatte livsfaser, for eksempel ved uhelbredelig sykdom. Det er derfor å forvente at forskjellige personer kan komme til helt forskjellige konklusjoner om hvorvidt en kontroversiell metode bør innføres i helsetjenesten, avhengig av politisk, verdimessig eller religiøst ståsted. Kostbare metoder med livsforlengende, men ikke helbredende, effekt, kan utløse intense og emosjonelt ladete diskusjoner.

Metodevurderinger presenterer forskningsdokumentasjon og konsekvenser ved innføring av en metode, og har sin funksjon ved å støtte kunnskapsbaserte beslutninger. De er ikke tenkt som forslag til beslutninger, men må alltid vurderes sammen med andre deler av beslutningsgrunnlaget. Selv om konklusjonen i en metodevurdering utelukkende bygger på oppsummering av tilgjengelig forskning om metoden, vil noen likevel kunne oppleve konklusjonen som provoserende.

Metodevurderinger bygger på en strikt og overprøvbar metodikk som er utarbeidet internasjonalt, blant annet gjennom europeisk samarbeid (9), og for metodevurderingsorganisasjoner er det viktig å kvalitetssikre at metodevurderinger er utført i overensstemmelse med denne metodikken. Dette sterke fokuset på metodikk kan i noen tilfeller oppfattes å gå på bekostning av metodevurderingens relevans $i$ den kliniske delen av helsetjenesten. Strenge inklusjons- og eksklusjonskriterier innebærer for eksempel at studier som ikke oppfyller inklusjonskriteriene som ble definert før arbeidet med metodevurderingen startet, ikke tas med, selv om noen av disse studiene kunne ha gitt viktige innspill til klinisk praksis. De fleste metodevurderingsorganisasjoner er klar over denne utfordringen, og jobber kontinuerlig med å finne en balanse mellom kravet om en streng og etterprøvbar metodikk på den ene siden og behovet for metodevurderinger som er relevante, både på overordnet politisk nivå og i klinisk praksis, på den andre siden.

Gjennomføring av en metodevurdering er en omfattende prosess. Ettersom det stadig produseres mer forskning, blir litteratursøk, gjennomlesning av sammendrag og artikler, kritisk vurdering og sammenfatning av resultater stadig mer ressurskrevende. Vanligvis vil en metodevurdering ta 6-12 måneder. Dette kan i noen tilfeller medføre at en metodevurdering er utdatert allerede ved publiseringstidspunktet. Det er derfor vanlig å avvente resultater av pågående studier om en metode, for eksempel større internasjonale multisenterstudier, før arbeidet med en metodevurdering starter. En annen tilnærming er å utføre oppdateringssøk mot slutten av arbeidet for å fange opp eventuelle nye studier som er publisert mens arbeidet med metodevurderingen pågikk. 


\section{KONKLUSJON}

Metodevurderinger eller HTA utføres for at nyttige metoder skal komme raskere ut til pasientene i den kliniske helsetjenesten. I de fleste tilfeller vil en metodevurdering inneholde en oppsummering av klinisk effekt og sikkerhet, samt kostnadseffektiviteten ved en metode. I tillegg kan vurdering av etiske, juridiske, sosiale eller organisatoriske konsekvenser av å innføre metoden være relevante. For å spare ressurser legges det opp til økt internasjonalt samarbeid om metodevurderinger, særlig ved deling av dokumentasjon om klinisk effekt og sikkerhet. I metodevurderingsorganisasjoner pågår et kontinuerlig arbeid med å utvikle og forbedre metodikken for utarbeiding av metodevurderinger, blant annet for å sikre relevans for klinikere og beslutningstakere i helsetjenesten.

\section{REFERANSER}

1. Mørland B. Piene H. Etablering og utvikling av medisinsk metodevurdering i Norge - hvorfor og hvordan? Michael 2012; 9: 95-108.

2. Arentz-Hansen H, Norderhaug IN, Jamtvedt G, Ormstad S, Fure B. Den nye lillesøsteren - forenklede metodevurderinger på lokalt nivå (mini-HTA). Michael 2012; 9: 118-126.

3. Fure B, Ormstad SS, Vang VJ, Lauvrak V, Frønsdal KB, Skår Å, Arentz-Hansen H. Mini-metodevurdering: Rask og trygg innføring av nye metoder i sykehus. Norsk Epidemiologi 2013; 23 (2): 171-175.

4. Norderhaug IN, Fure B, Reinar LM, Klemp M, Jamtvedt G. Hva er en metodevurdering (HTA), en systematisk oversikt og en metaanalyse - når og hvordan brukes de? Michael 2012; 9: 109-117.

5. Jamtvedt G. Systematiske oversikter om effekt av tiltak. Norsk Epidemiologi 2013; 23 (2): 119-124.

6. Smedslund G. Metaanalyse. Norsk Epidemiologi 2013; 23 (2): 147-149.

7. Lauvrak V, Norderhaug IN, Hagen G, Movik E, Acharya G, Forus A, et al. Tidlig ultralyd i svangerskapsomsorgen. Notat. Oslo: Nasjonalt kunnskapssenter for helsetjenesten, 2012.

8. Wisløff T, Ringerike T, Hagen G, Reikvam Å, Klemp M. Report from NOKC 05-2013. Oslo: Nasjonalt kunnskapssenter for helsetjenesten, 2013.

9. European Network for Health Technology Assessment (EUnetHTA). www.eunethta.eu (13.08.13).

10. Health Technology Assessment International. www.htai.org (13.08.13).

11. International Network of Agencies for Health Technology Assessment. www.inahta.net (13.08.13). 